\title{
Growth Parameters and Survivability of Saccharomyces boulardii for Probiotic Alcoholic Beverages Development
}

\author{
Breno Pereira de Paula1,2*, Davy William Hidalgo Chávez ${ }^{3}$, \\ Wilson José Fernandes Lemos Junior ${ }^{4}$, André Fioravante Guerra ${ }^{1}$, \\ Mariana Ferreira Dutra Corrêa ${ }^{5}$, Karen Signori Pereira ${ }^{5}$ and Maria Alice Zarur Coelho ${ }^{2,5}$ \\ ${ }^{1}$ Coordenadoria do Curso de Engenharia de Alimentos, Centro Federal de Educação Tecnológica Celso Suckow da \\ Fonseca, Valença, Brazil, ${ }^{2}$ Programa de Pós-Graduação em Ciência de Alimentos, Universidade Federal do Rio de Janeiro, \\ Rio de Janeiro, Brazil, ${ }^{3}$ Departamento de Tecnologia de Alimentos, Universidade Federal Rural do Rio de Janeiro, \\ Seropédica, Brazil, ${ }^{4}$ Department of Biotecnology, University of Verona, Verona, Italy, ${ }^{5}$ Escola de Química, Universidade \\ Federal do Rio de Janeiro, Rio de Janeiro, Brazil
}

OPEN ACCESS

Edited by:

Lin Lin,

Jiangsu University, China

Reviewed by:

Antonio Bevilacqua

University of Foggia, Italy

Dimitris Tsaltas,

Cyprus University of Technology,

Cyprus

Bruno Douradinha,

Ri.MED Foundation, Italy

*Correspondence:

Breno Pereira de Paula

brenoea/@gmail.com

Specialty section:

This article was submitted to

Food Microbiology,

a section of the journa

Frontiers in Microbiology

Received: 25 May 2019

Accepted: 26 August 2019

Published: 10 September 2019

Citation:

Paula BP, Chávez DWH, Lemos Junior WJF, Guerra AF Corrêa MFD, Pereira KS and Coelho MAZ (2019) Growth

Parameters and Survivability

of Saccharomyces boulardii for Probiotic Alcoholic Beverages

Development.

Front. Microbiol. 10:2092. doi: 10.3389/fmicb.2019.02092
The aim of this research was to optimize the growth parameters $(\mathrm{pH}$, ethanol tolerance, initial cell concentration and temperature) for Saccharomyces boulardii and its tolerance to in vitro gastrointestinal conditions for probiotic alcoholic beverage development. Placket-Burman screening was used to select only statistically significant variables, and the polynomial mathematical model for yeast growth was obtained by central composite rotatable design. Confirmation experiments to determine the kinetic parameters for yeast growth were carried out by controlling the temperature and $\mathrm{pH}$. Soon after, the survivability of yeast was tested under in vitro conditions mimicking the human upper gastrointestinal transit. S. boulardii had suitable resistance to alcohol and gastrointestinal conditions for probiotic alcoholic beverage development.

Keywords: functional beverage, alcoholic resistance, yeast, gut, dysbiosis

\section{INTRODUCTION}

Eating habits have changed over the decades in pursuit of a healthier diet. Therefore, food and drink are being consumed with the purpose of disease prevention or treatment instead of only basic nutrition. Probiotics are live microorganisms that, when administered in adequate amounts, confer a health benefit on the host (Joint FAO/WHO Working Group, 2002). Properly controlled studies on probiotics microbial to confer benefits to health have been included to the probiotic definitions. Additionally, new commensals and consortia comprising defined strains from human samples, with adequate evidence of safety and efficacy, are also "probiotics" (Hill et al., 2014). Probiotic food matrices should ensure the survivability of probiotic microorganisms throughout the gastrointestinal tract (Spigno et al., 2015). The majority of probiotic strains are intended for gut health improvement (Floch, 2017). However, probiotic strains must resist gastrointestinal conditions to benefit gut health.

Lactic acid bacteria are the main strains used as probiotics, but some Saccharomyces sp., Escherichia coli and Bacillus sp. have also been employed (Fijan, 2014). Saccharomyces sp. is a yeast, belonging to the kingdom Fungi, and has suitable features for brewing, such as the ability to metabolize high sugar concentrations in a large range of $\mathrm{pH}$ values, nitrogen levels, and 
temperatures (Lemos Junior et al., 2017). Saccharomyces boulardii is classified as a subtype of Saccharomyces cerevisiae and was first isolated from mangosteen and lychee by Henri Boulardii in 1923 (Altmann, 2018). S. boulardii is unique probiotic and biotherapeutic yeast, known to survive in gastric acidity and it is not adversely affected or inhibited by antibiotics or does not alter or adversely affect the normal micro biota (Tomičić et al., 2016). Its consumption provides several benefits for human health, such as travelers' diarrhea, irritable bowel syndrome (IBS), colitis and related malaise, such as inflammatory bowel, Crohn's disease, acute gastroenteritis, chronic diarrhea in HIV-infected caused by Clostridium difficile, Vibrio cholerae, and other pathogenic enterobacteria (Szajewska and Kołodziej, 2015; Bagherpour et al., 2018; Terciolo et al., 2019).

Regarding to methodologies, the development, production or optimization of new products are not a simple task due to the high cost of process and reagents and the increments of requirements of regulatory agencies. In this sense, the design of experiments (DOE) and response surface methodology (RSM) are important issues because its takes less time, effort, and resources as well as facilitates the collection of a large amount of information with minimizing the number of experiments (Candioti et al., 2014). RSM has been demonstrated to be efficient for developing, improving, and optimizing processes, and it has been broadly used in analytical applications, industrial world, and bioprocesses (Adinarayana et al., 2003; Kristo et al., 2003; Lee and Gilmore, 2005; Zhi et al., 2005; Myers et al., 2016).

On the other hand, alcoholic fermented beverages are consumed extensively worldwide, mainly for the welfare (Silva et al., 2016). Although a lot of information about an alcoholic beverage, researchers regarding probiotic alcoholic beverages and its optimization by applying RSM are needing. Thus, development probiotic alcoholic beverages present new challenge and possibilities for the delivery of probiotic yeast and add some functional features to alcoholic beverage consumption.

For the reason above mentioned, the aim of this research was to applying RSM to optimize the growth parameters for S. boulardii $(\mathrm{pH}$, alcohol content, initial cell concentration, and temperature) in synthetic must and its tolerance under conditions that mimic in vivo human upper gastrointestinal transit, thereby facilitating probiotic alcoholic beverage development.

\section{MATERIALS AND METHODS}

\section{Microbial Isolation and Standardization of Working Inoculum}

Saccharomyces boulardii - 17 (Floratil ${ }^{\circledR}$ 200, Merck, France) was obtained by streaking on Sabouraud agar media (HiMedia, Mumbai, India) followed by incubation at $25^{\circ} \mathrm{C}$ for $48 \mathrm{~h}$. A single colony was picked with a sterile loop and transferred to a tube containing yeast-extract-peptone-dextrose (YPD) broth. After incubation overnight at $25^{\circ} \mathrm{C}$, the working inoculum was obtained in YPD at the same temperature under gentle shaking $\left(160 \mathrm{~min}^{-1}\right)$. After growth, the cells were harvested by centrifugation at $6000 \times g$ for $5 \mathrm{~min}$. The liquid fraction was discarded, and the remaining cell pellet was washed twice with phosphate buffer $\mathrm{pH} 7.2$ and resuspended in the same buffer up to an optical density at $620 \mathrm{~nm}\left(\mathrm{OD}_{620 \mathrm{~nm}}\right)$ measurement corresponding to ca. $10^{8} \mathrm{cfu} \mathrm{mL}^{-1}$.

\section{Determination of the Cellular Concentration}

Cell concentration determinations performed during the culture of $S$. boulardii were expressed as dry weight $\left(\mathrm{X}_{\mathrm{dw}}\right)$ and viable cells $\left(\mathrm{X}_{\mathrm{vc}}\right)$.

Dry weight $\left(\log _{10} \mathrm{~g}\right.$ dry weight $\left.\mathrm{L}^{-1}\right)$ were determined from centrifuged samples by discarding the supernatant and resuspending the pellet in $100 \mathrm{~mL}$ of distilled water. Subsequently, the cell suspension was diluted 1:100 to quantify the optical density at $620 \mathrm{~nm}\left(\mathrm{OD}_{620 \mathrm{~nm}}\right)$ in a spectrophotometer (Biospectro model Spectrum SP-2000UV, Brazil) within the linearity range $(0.050$ to 0.500$)$. The $\mathrm{OD}_{620 \mathrm{~nm}}$ values were related to the dry weight of the cell suspensions filtered on cellulose acetate membranes with $0.45 \mu \mathrm{m}$ pore diameter and dehydrated in a chamber with infrared radiation to construct a calibration curve and obtain the conversion factor of $\mathrm{OD}_{620 \mathrm{~nm}}$ in Dry weight.

Viable cells ( $\log _{10}$ viable cells $\mathrm{mL}^{-1}$ ) was determined by mixing equal parts of the appropriately diluted cell suspension with methylene blue solution $\left(0.1 \% \mathrm{~m} \mathrm{v}^{-1}\right)$. The solution was observed in a Neubauer chamber using an optical microscope [Biofocus (R), United States].

\section{Substrate Consumption and Product Generation Measurement}

Saccharomyces boulardii metabolic sugar consumption (glucose) and product formation (glycerol, ethanol, and acetic acid) were analyzed using a high-performance liquid chromatography system equipped with an infrared detector, binary pump, control module, and LabSolution chromatography software (Shimadzu ${ }^{\circledR}$, Japan). The chromatography column used was an Aminex ${ }^{\circledR}$ HPX-87H $300 \mathrm{~mm} \times 7.8 \mathrm{~mm}$ (Bio-Rad Laboratories Ltd., United States). The mobile phase was prepared in $5 \mathrm{mM} \mathrm{H}_{2} \mathrm{SO}_{4}$ at a flow rate of $0.8 \mathrm{~mL} \mathrm{~min}{ }^{-1}$. The injection volume was set to $20 \mu \mathrm{L}$, and the temperature was set to $60^{\circ} \mathrm{C}$.

\section{pH Measurement}

A benchtop pH meter (MPA-201, Tecnopon, Brazil) with a digital microprocessor equipped with automatic temperature compensation, calibrated with $\mathrm{pH} 4.0$ buffer (citric acid, sodium hydroxide, and hydrogen chloride, Merck ${ }^{\circledR}$, France) and pH 7.0 buffer (potassium dihydrogen phosphate and disodium hydrogen phthalate, Merck ${ }^{\circledR}$, France), was used for $\mathrm{pH}$ measurements.

\section{Optimizing Saccharomyces boulardii Growth Conditions}

Saccharomyces boulardii growth optimization was carried out by determining independent variables with significant influence on growth, in accordance with Plackett and Burman matrix (Plackett and Burman, 1946); optimization by central composite rotatable design (CCRD); and polynomial mathematical model validation. Plackett and Burman design was made with a $22_{\text {IV }}^{4-1}$ fractional factorial experiment (four factors), each of them with two levels, 
and three central points be able to check the curvature, the mathematical model for Plackett and Burman is in Eq. 1.

$$
Y=\beta_{0}+\sum_{i=1}^{k} \beta_{i} X_{i}+\sum_{i=1}^{k} \beta_{i i} X_{i}^{2}
$$

Where $\mathrm{Y}$ is predicted response; $\mathrm{i}$ and ii are linear and quadratic coefficients, respectively; $\beta$ are regression coefficient and $k$ is the number of factors.

One possible design to evaluated the four independent variables (alcohol content - AC, potential of hydrogen - $\mathrm{pH}$, initial cell concentration $-\mathrm{X}_{0}$, and temperature $-\mathrm{T}$ ) could be the $2^{\mathrm{k}}$ full factorial $(k=4)$. In this case, the total number of treatments will be 16 and, considering three repetitions, it will totalize 48 runs. Another disadvantage of full $2^{\mathrm{k}}$ factorial design would be that it only have two levels, and it will be impossible to detect the possible curvature effect. A $3^{\mathrm{k}}$ full factorial $(k=4)$ is able to evaluate the curvature effect but it would have 81 treatments totalizing 243 runs with 3 repetitions. On the other hand, a Plackett and Burman design with central points for four variables only need 11 runs with the advantage in detecting the possible curvature effect. Thus, four independent variables (alcohol content - AC, potential of hydrogen - $\mathrm{pH}$, initial cell concentration $-\mathrm{X}_{0}$, and temperature $-\mathrm{T}$ ) were evaluated for screening performance at three different levels. Eight factorial point combinations $( \pm 1)$ and three central points, for a total of 11 trials (Table 1), were generated. Miniaturized tests $(10 \mathrm{~mL}$, screwcap tubes) were performed in accordance with the experimental design in YPD. Biomass formation $\left(\mathrm{X}_{\mathrm{dw}}\right)$, measured by $\mathrm{OD}_{620 \mathrm{~nm}}$ every $24 \mathrm{~h}$, was the dependent variable.

From the screening results, central composite rotatable design was performed using the independent variables alcohol content, $\mathrm{pH}$, and temperature. Cellular concentration in dry weight and viable cells were used as dependent variables. Five levels by dependent variable including eight factorial points $( \pm 1)$, six axial points $( \pm \alpha)$, and five central points to estimate the pure error

TABLE 1 | Eleven trials in Plackett and Burman (PB 8) experimental design for Saccharomyces boulardii growth.

\begin{tabular}{lccccc}
\hline Test & $\mathbf{A C}$ & $\mathbf{p H}$ & $\mathbf{\mathbf { X } _ { \mathbf { 0 } }}$ & $\mathbf{T}$ & $\mathbf{X}_{\mathbf{d w}} \pm \mathbf{S D}$ \\
\hline 1 & $+1(11.30)$ & $-1(3.30)$ & $-1\left(1 \times 10^{2}\right)$ & $+1(21.3)$ & $-1.85 \pm 0.00$ \\
2 & $+1(11.30)$ & $+1(5.80)$ & $-1\left(1 \times 10^{2}\right)$ & $-1(13.8)$ & $-1.59 \pm 0.02$ \\
3 & $+1(11.30)$ & $+1(5.80)$ & $+1\left(1 \times 10^{5}\right)$ & $-1(13.8)$ & $-1.54 \pm 0.01$ \\
4 & $-1(3.80)$ & $+1(5.80)$ & $+1\left(1 \times 10^{5}\right)$ & $+1(21.3)$ & $-0.54 \pm 0.01$ \\
5 & $-1(3.80)$ & $-1(3.30)$ & $+1\left(1 \times 10^{5}\right)$ & $+1(21.3)$ & $-2.03 \pm 0.02$ \\
6 & $-1(3.80)$ & $+1(5.80)$ & $-1\left(1 \times 10^{2}\right)$ & $+1(21.3)$ & $-0.54 \pm 0.00$ \\
7 & $+1(11.30)$ & $-1(3.30)$ & $+1\left(1 \times 10^{5}\right)$ & $-1(13.8)$ & $-2.44 \pm 0.06$ \\
8 & $-1(3.80)$ & $-1(3.30)$ & $-1\left(1 \times 10^{2}\right)$ & $-1(13.8)$ & $-2.32 \pm 0.06$ \\
9 & $0(7.55)$ & $0(4.55)$ & $0\left(5 \times 10^{4}\right)$ & $0(17.6)$ & $-0.61 \pm 0.01$ \\
10 & $0(7.55)$ & $0(4.55)$ & $0\left(5 \times 10^{4}\right)$ & $0(17.6)$ & $-0.57 \pm 0.03$ \\
11 & $0(7.55)$ & $0(4.55)$ & $0\left(5 \times 10^{4}\right)$ & $0(17.6)$ & $-0.64 \pm 0.01$ \\
\hline
\end{tabular}

$\overline{A C}$, alcohol content ( $\left.{ }^{\circ} \mathrm{GL}\right) ; \mathrm{pH}$, potential of hydrogen; $X_{0}$, initial cell concentration (cells $\left.m L^{-1}\right) ; T$, incubation temperature $\left({ }^{\circ} \mathrm{C}\right) ; X_{d w}$, biomass formation $\left(\log _{10}\right.$ $g$ of dry weight $\left.L^{-1}\right)$; $S D$, standard deviation $(n=3)$. Real values are shown in parentheses. were evaluated, for a total of 19 trials (Table 2). The mathematical model for CCRD is presenting in Eq. 2.

$$
Y=\beta_{0}+\sum_{i=1}^{k} \beta_{i} X_{i}+\sum_{i=1}^{k} \beta_{i i} X_{i}^{2}+\sum_{i=1}^{k} \sum_{j=1}^{k} \beta_{i j} X_{i} X_{j}
$$

Where $\mathrm{Y}$ is predicted response; $\mathrm{i}$, ii, and ij are linear, quadratic, and interaction coefficients, respectively; $\beta$ are regression coefficient; and $\mathrm{k}$ is the number of factors.

Additionally, desirability functions was performed to optimization of simultaneous multiple responses. According to Myers et al. (2016), the first approach is to convert each response $\left(Y_{\mathrm{i}}\right)$ into an individual desirability $\left(d_{\mathrm{i}}\right)$ varying from 0 to 1 , and then obtain the overall desirability (D) applying the geometric median according Eq. 3.

$$
D=\sqrt[\sum]{d_{1}^{w 1} \cdot d_{2}^{w 2} \ldots d_{m}^{w_{m}}}
$$

Were $d_{\mathrm{i}}$ is the individual desirability, and $m$ are the number of responses used to carried out the overall desirability (D) and $w$ is the weight attributed for each response.

Each desirability is calculating according the objective for each variable, thus it could target for the response to be at minimum (Eq. 4).

$$
d=\left\{\begin{array}{cc}
0, & y<L \\
\left(\frac{y-L}{T-L}\right)^{r}, & L \leq y \leq T \\
1, & y>T
\end{array}\right.
$$

Where $r$ is a weight used to determine the scale of desirability, if $r=1$, the desirability function is linear, if $r>1$ places more emphasis on being close to the target value, and choosing $0 \leq r \leq 1$ makes this less important. $y$ is the response value, $L$ is the minimum acceptable response, and $T$ is the maximum acceptable response (Derrien et al., 2017).

A bioreactor (SL-135, Solab, Brazil) with the working volume filled (5 L) with YPD containing added alcohol $\left(5.0^{\circ} \mathrm{GL}\right)$ and the $\mathrm{pH}$ adjusted to 5.5 was incubated at $24^{\circ} \mathrm{C}$ to confirm the adequacy of the developed polynomial mathematical model to maximize yeast growth.

\section{Determination of Kinetic Parameters}

A polynomial mathematical model validation assay was developed to determine the kinetic parameters (generation time $-t_{g}$, specific growth rate $-\mu_{X}$, rate of substrate utilization $\mu_{S}$, and conversion factor of substrate into biomass - $\left.\mathrm{Y}_{\mathrm{X} / \mathrm{S}}\right)$ for $S$. boulardii growth (X) and substrate consumption (S), in accordance with Eqs. 5-8.

$$
\begin{aligned}
t_{g} & =\frac{\operatorname{Ln} 2}{\mu_{m}} \\
\mu_{m}=\frac{1}{X} \frac{d X}{d t} & =\frac{\ln X-\ln X_{0}}{t-t_{0}}
\end{aligned}
$$


TABLE 2 | Central composite rotatable design $\left(\mathrm{CCRD} 2^{3}\right)$ for S. boulardii growth.

\begin{tabular}{|c|c|c|c|c|c|c|c|c|c|}
\hline \multirow[t]{2}{*}{ Teste } & \multirow[t]{2}{*}{ AC } & \multirow[t]{2}{*}{$\mathrm{pH}$} & \multirow[t]{2}{*}{$\mathbf{T}$} & \multicolumn{3}{|c|}{ Biomass formation } & \multicolumn{3}{|c|}{ Viable cells } \\
\hline & & & & $\mathrm{X}_{\mathrm{dw}} \pm \mathrm{SD}$ & PV & RD & $\mathrm{X}_{\mathrm{vc}} \pm \mathrm{SD}$ & PV & RD \\
\hline 1 & $-1(3.0)$ & $-1(5.00)$ & $-1(18.5)$ & $-0.60 \pm 0.01$ & -0.53 & -12.20 & $8.16 \pm 0.02$ & 8.18 & 0.24 \\
\hline 2 & $-1(3.0)$ & $-1(5.00)$ & $+1(23.5)$ & $-0.36 \pm 0.00$ & -0.33 & -9.01 & $8.56 \pm 0.01$ & 8.51 & -0.61 \\
\hline 3 & $-1(3.0)$ & $+1(6.00)$ & $-1(18.5)$ & $-0.57 \pm 0.02$ & -0.53 & -8.01 & $8.45 \pm 0.02$ & 8.49 & 0.46 \\
\hline 4 & $-1(3.0)$ & $+1(6.00)$ & $+1(23.5)$ & $-0.30 \pm 0.00$ & -0.24 & -26.45 & $8.55 \pm 0.02$ & 8.61 & 0.69 \\
\hline 5 & $+1(11.8)$ & $-1(5.00)$ & $-1(18.5)$ & $-2.19 \pm 0.04$ & -1.92 & -14.05 & $6.61 \pm 0.04$ & 6.83 & 3.21 \\
\hline 6 & $+1(11.8)$ & $-1(5.00)$ & $+1(23.5)$ & $-2.36 \pm 0.03$ & -2.06 & -14.38 & $6.56 \pm 0.04$ & 6.80 & 3.47 \\
\hline 7 & $+1(11.8)$ & $+1(6.00)$ & $-1(18.5)$ & $-2.13 \pm 0.02$ & -1.82 & -17.10 & $6.71 \pm 0.06$ & 7.04 & 4.63 \\
\hline 8 & $+1(11.8)$ & $+1(6.00)$ & $+1(23.5)$ & $-2.15 \pm 0.10$ & -1.88 & -14.60 & $6.54 \pm 0.06$ & 6.80 & 3.76 \\
\hline 9 & $-1.68(0.0)$ & $0(5.50)$ & 0 (21.0) & $-0.31 \pm 0.00$ & -0.29 & -8.38 & $8.59 \pm 0.05$ & 8.67 & 0.96 \\
\hline 10 & $+1.68(14.8)$ & $0(5.50)$ & $0(21.0)$ & $-2.31 \pm 0.14$ & -2.83 & 18.35 & $6.48 \pm 0.01$ & 6.01 & -7.80 \\
\hline 11 & $0(7.4)$ & $-1.68(4.66)$ & $0(21.0)$ & $-0.75 \pm 0.00$ & -0.99 & 24.57 & $7.81 \pm 0.02$ & 7.68 & -1.74 \\
\hline 12 & $0(7.4)$ & +1.68 (6.34) & $0(21.0)$ & $-0.57 \pm 0.01$ & -0.83 & 31.43 & $8.20 \pm 0.03$ & 7.94 & -3.33 \\
\hline 13 & $0(7.4)$ & $0(5.50)$ & $-1.68(16.8)$ & $-0.74 \pm 0.01$ & -0.99 & 25.46 & $8.08 \pm 0.01$ & 7.86 & -2.82 \\
\hline 14 & $0(7.4)$ & $0(5.50)$ & $+1.68(25.2)$ & $-0.62 \pm 0.00$ & -0.87 & 28.64 & $8.11 \pm 0.00$ & 7.93 & -2.25 \\
\hline 15 & $0(7.4)$ & $0(5.50)$ & $0(21.0)$ & $-0.66 \pm 0.00$ & -0.65 & -1.77 & $8.10 \pm 0.01$ & 8.10 & -0.03 \\
\hline 16 & $0(7.4)$ & $0(5.50)$ & $0(21.0)$ & $-0.66 \pm 0.00$ & -0.65 & -1.77 & $8.08 \pm 0.00$ & 8.10 & 0.22 \\
\hline 17 & $0(7.4)$ & $0(5.50)$ & $0(21.0)$ & $-0.66 \pm 0.00$ & -0.65 & -1.77 & $8.09 \pm 0.01$ & 8.10 & 0.10 \\
\hline 18 & $0(7.4)$ & $0(5.50)$ & $0(21.0)$ & $-0.66 \pm 0.00$ & -0.65 & -1.77 & $8.06 \pm 0.02$ & 8.10 & 0.47 \\
\hline 19 & $0(7.4)$ & $0(5.50)$ & $0(21.0)$ & $-0.66 \pm 0.00$ & -0.65 & -1.77 & $8.09 \pm 0.03$ & 8.10 & 0.10 \\
\hline
\end{tabular}

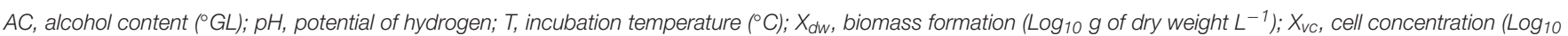

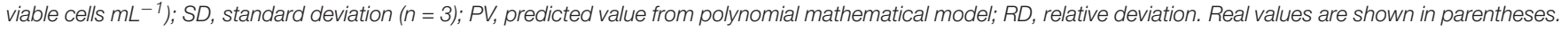

$$
\begin{aligned}
Y_{X S^{-1}} & =-\frac{d X}{d S}=-\frac{X-X_{0}}{S-S_{0}} \\
\mu_{S} & =-\frac{1}{X} \frac{d S}{d t}=\frac{\mu_{m}}{Y_{X S^{-1}}}
\end{aligned}
$$

Here, $t_{g}$ - generation time, from exponential growth phase (h), $\mu_{m}$ - specific speed for maximum growth, from log phase $\left(\mathrm{h}^{-1}\right), \mathrm{X}_{0}$ - initial concentration of viable cells (cells $\left.\mathrm{L}^{-1}\right), \mathrm{X}-$ concentration of viable cells (cells $\mathrm{L}^{-1}$ ), $\mathrm{S}_{0}$ - initial concentration of glucose $\left(\mathrm{g} \mathrm{L}^{-1}\right), \mathrm{S}$ - concentration of glucose $\left(\mathrm{g} \mathrm{L}^{-1}\right), \mathrm{t}_{0}-$ initial time of $\log$ phase development $(\mathrm{h})$, and $\mathrm{t}$ - final time of $\log$ phase (h).

\section{Tolerance to Challenges Mimicking Gastrointestinal Transit}

To evaluate $S$. boulardii survivability under in vitro gastrointestinal conditions, $10 \mathrm{~mL}$ aliquots from the polynomial mathematical model validation experiment samples were collected as described above. In vitro GI treatment was carried out as reported by Guerra et al. (2018) and Lemos Junior et al. (2019). GI base juice was formulated as follows: $0.11 \mathrm{~g}$ $\mathrm{L}^{-1}$ calcium chloride, $1.12 \mathrm{~g} \mathrm{~L}^{-1}$ potassium chloride, $2.0 \mathrm{~g} \mathrm{~L}^{-1}$ sodium chloride, and $0.4 \mathrm{~g} \mathrm{~L}^{-1}$ potassium dihydrogen phosphate. This solution was sterilized at $121^{\circ} \mathrm{C}$ for $15 \mathrm{~min}$. Artificial gastric juice (GJ) was freshly prepared $(75 \mathrm{~mL})$ by adding $3.5 \mathrm{~g} \mathrm{~L}^{-1}$ swine mucin and $0.26 \mathrm{~g} \mathrm{~L}^{-1}$ swine pepsin (SigmaAldrich, S. Louis, MO, United States). The $\mathrm{pH}$ was adjusted to 2.0 with 1.0 $\mathrm{M} \mathrm{HCl}$. Sample aliquots $(1 \mathrm{~mL})$ was transferred into GJ and anaerobically incubated at $36^{\circ} \mathrm{C}$ for $45 \mathrm{~min}$, with gentle shaking. Subsequently, artificial intestinal juice was obtained by adding $3.0 \mathrm{~g} \mathrm{~L}^{-1}$ bile salt, $1.95 \mathrm{~g} \mathrm{~L}^{-1}$ pancreatin, and $0.1 \mathrm{~g} \mathrm{~L}^{-1}$ egg white lysozyme (SigmaAldrich, S. Louis, MO, United States) to the GJ. Sterile distilled water was used to top up $100 \mathrm{~mL}$ final volume. The $\mathrm{pH}$ was adjusted to 7.0 with $1.0 \mathrm{M}$ sodium bicarbonate solution and anaerobically incubated at $36^{\circ} \mathrm{C}$ for 180 min, with gentle shaking. 12-wells microtiter plate with WL agar (SigmaAldrich, S. Louis, MO, United States) was used to count viable cells by drop plate technique both after growing in YPD medium and gastric and GI treatment, so that each well was seeded by only a drop from each dilution level - until $10^{-6}$. Plates were incubated at $30^{\circ} \mathrm{C}$ for $48 \mathrm{~h}$, under aerobic condition. Colonies were quantified with the aid of colony counter. The results were expressed as weighted $\left(\log _{10} \mathrm{cfu}\right.$ $\mathrm{mL}^{-1}$ ), using at least two successive dilutions level, according to ISO 7218 (2007).

\section{Statistical Analysis}

The results were reported as the mean \pm standard deviation (SD) $(n=3)$ and analyzed by a variance test (ANOVA) followed by Fischer's or Dunnett's test. Statistica software version 10.0 (StatSoft, Tulsa, United States) was used for the central composite rotatable design analyses. A desirability function was used to obtain the preferred conditions of the dependent variables as a function of cellular concentration in dry weight and viable cells. Action Stat software version 3.1.43.724.694 (ESTATCAMP, Brazil) was used for other statistical analyses. All statistical analyses were performed at $95 \%$ confidence. 

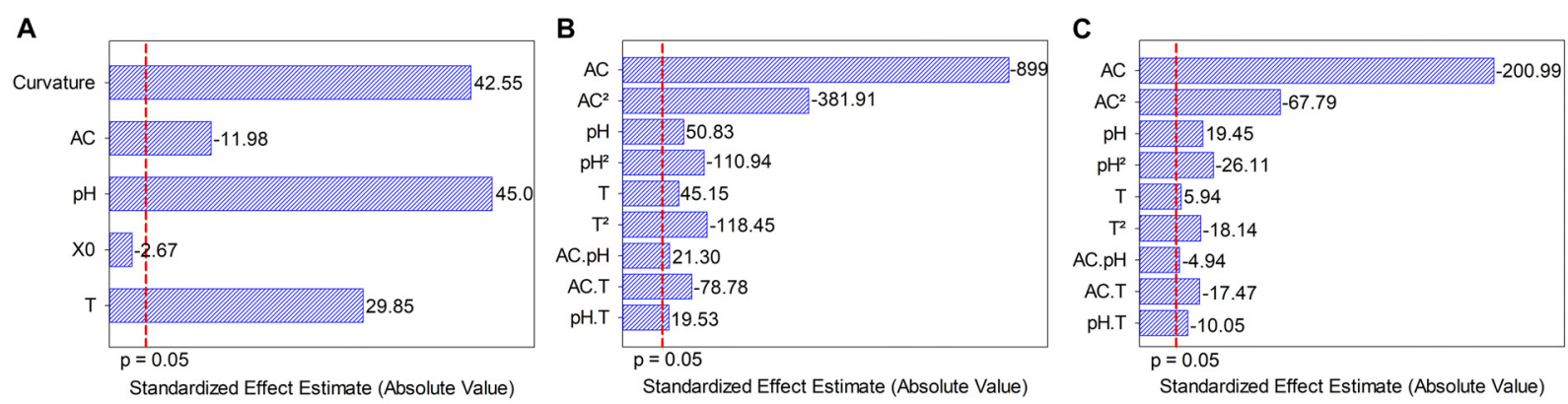

FIGURE 1 | (A) Pareto chart of the standardized effects of independent variables on biomass formation. (B) Pareto chart of standardized effects from model terms for the independent variables on biomass formation. (C) Pareto chart of standardized effects from model terms for the independent variables on Saccharomyces boulardii viability. $\mathrm{AC}$, alcohol content $\left({ }^{\circ} \mathrm{GL}\right) ; \mathrm{pH}$, potential of hydrogen; $\mathrm{X}_{0}$, initial $\mathrm{S}$. boulardii concentration $\left(\mathrm{cells} \mathrm{mL}{ }^{-1}\right)$; $\mathrm{T}$, temperature $\left({ }^{\circ} \mathrm{C}\right)$.

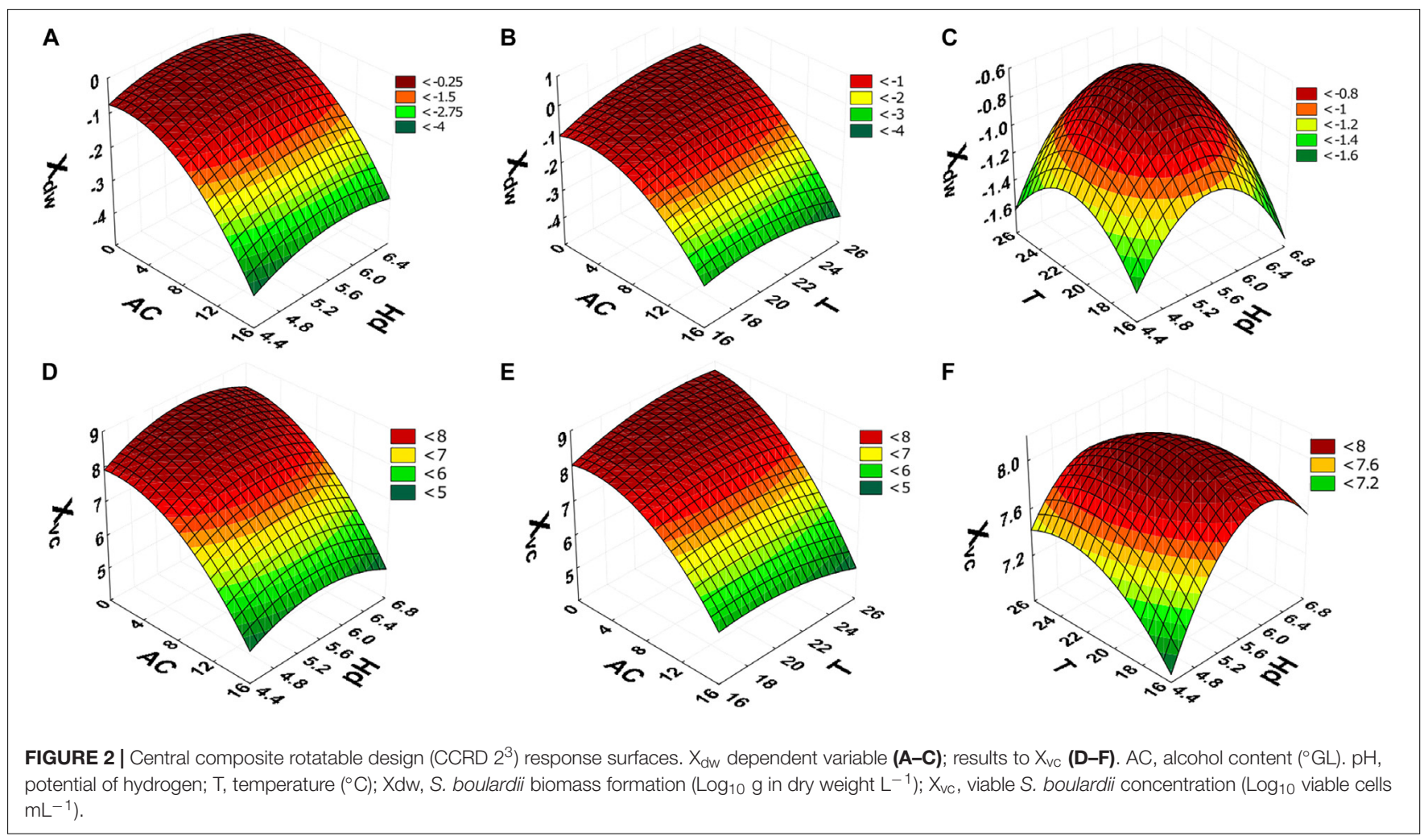

\section{RESULTS}

\section{Screening on the Laboratory Scale}

The screening results revealed that alcohol content had a negative effect on dry weight, whereas temperature and $\mathrm{pH}$ had a positive effect on dry weight. Initial S. boulardii concentration was not significant (Figure 1A). The Plackett and Burman design showed a significant curvature $(p<0.05)$, indicating that the optimal point was among the levels tested. Three independent variables $(\mathrm{pH}$, temperature and alcohol content) were defined as significant for the central composite rotatable design optimization.

The initial S. boulardii concentration effect was lower than that of other variables (approximately 4.5, 16.9 and 11.2 times lower than the effects of alcohol content, $\mathrm{pH}$, and temperatura, respectively) and had no significant influence on dry weight. Based on the Plackett and Burman results, temperature ( 16.8 up to $25.2^{\circ} \mathrm{C}$ ) and $\mathrm{pH}\left(4.66\right.$ up to $6.34^{\circ} \mathrm{C}$ ) were adjusted to maximize the growth of Saccharomyces boulardii, and alcohol content $\left(0.0\right.$ up to $\left.14.8^{\circ} \mathrm{GL}\right)$ was extended to determine its growth ability in the presence of alcohol to maximize cellular concentration in dry weight and viable cells in central composite rotatable design performance. All coefficients (Figures 1B,C) from the polynomial mathematical models show statistical significance for cellular concentration in dry weight and viable cells, including the interactions among independent variables $(p \leq 0.05)$, determination coefficient $\left(R^{2}\right)$ values (0.9154 and 0.9347) and adjusted $R^{2}(0.8308$ and 0.8693$)$. 


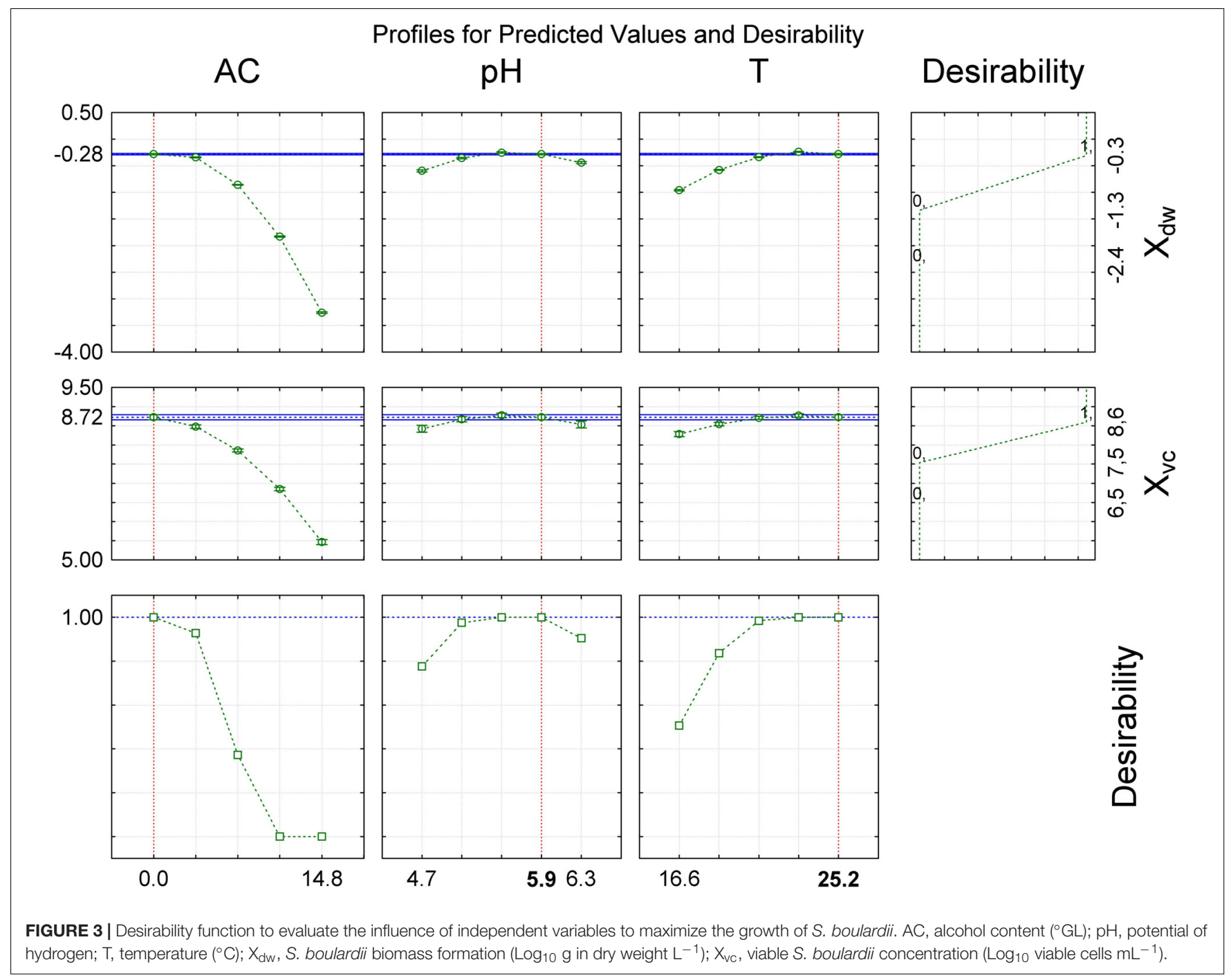

A p (lack of fit) $<0.0001$ indicates the adequacy of the models, Eqs (9) and (10).

$$
\begin{aligned}
X_{d w}= & -18.3197+0.1809 A C-0.0166 A C^{2}+3.7762 p H \\
& -0.3745 p H^{2}+0.6506 T-0.0160 T^{2}+0.0107 A C p H \\
& -0.0079 A C T+0.0172 p H T \\
X_{v c}= & -16.4677+0.2604 A C-0.0138 A C^{2}+5.6558 p H \\
& -0.4131 p H^{2}+0.7807 T-0.0115 T^{2}-0.0116 A C p H \\
& -0.0082 A C T-0.0415 p H T
\end{aligned}
$$

The surface response graphs (Figures 2A-F) show that the ranges of alcohol content, $\mathrm{pH}$ and temperature were adequate to maximize cellular concentration in dry weight and viable cells, indicating that the laboratoryscale experiment was optimized. In accordance with the polynomial mathematical models and maximum value of desirability function $\left(d_{\mathrm{i}}\right)\left(0.00 \leq d_{\mathrm{i}} \leq 1.00\right)$, cellular concentration in dry weight and viable cells were maximized with alcohol content $\left(0.0^{\circ} \mathrm{GL}\right), \mathrm{pH}$ (5.92), and temperature $\left(25.2^{\circ} \mathrm{C}\right)$ (Figure 3).

\section{Validation of the PMM in a 5 L Bioreactor}

For polynomial mathematical model validation, the stationary phase was considered at the first time point $(37.5 \mathrm{~h})$, where dry weight was $-0.61 \log _{10} \mathrm{~g}$ dry weight $\mathrm{L}^{-1}$. The predicted value from polynomial mathematical models was $-0.37 \log _{10} \mathrm{~g}$ dry weight $\mathrm{L}^{-1}$; therefore, a large relative deviation (63.74\%) was observed. However, the viable cell concentration values in the laboratory experiment $\left(7.63 \log _{10}\right.$ viable cells $\mathrm{mL}^{-1}$ ) and the polynomial mathematical model (8.43 $\log _{10}$ viable cells $\mathrm{mL}^{-1}$ ) were closer, with a relative deviation of $9.54 \%$.

The adaptation phase (lag) for polynomial mathematical model validation was up to $3 \mathrm{~h}$ after inoculating $S$. boulardii. The growth acceleration phase was from 3 to $14.5 \mathrm{~h}$, followed by the exponential growth phase up to $35.76 \mathrm{~h}$ (Figure 4), in accordance with linear regression $\left(R^{2}=0.9957 \mathrm{e} p<0.0001\right)$. The values of $\mathrm{t}_{\mathrm{g}}$ $(3.50 \mathrm{~h})$ and $\mu_{\mathrm{X}}\left(0.20 \mathrm{~h}^{-1}\right)$ were calculated from the log phase. 


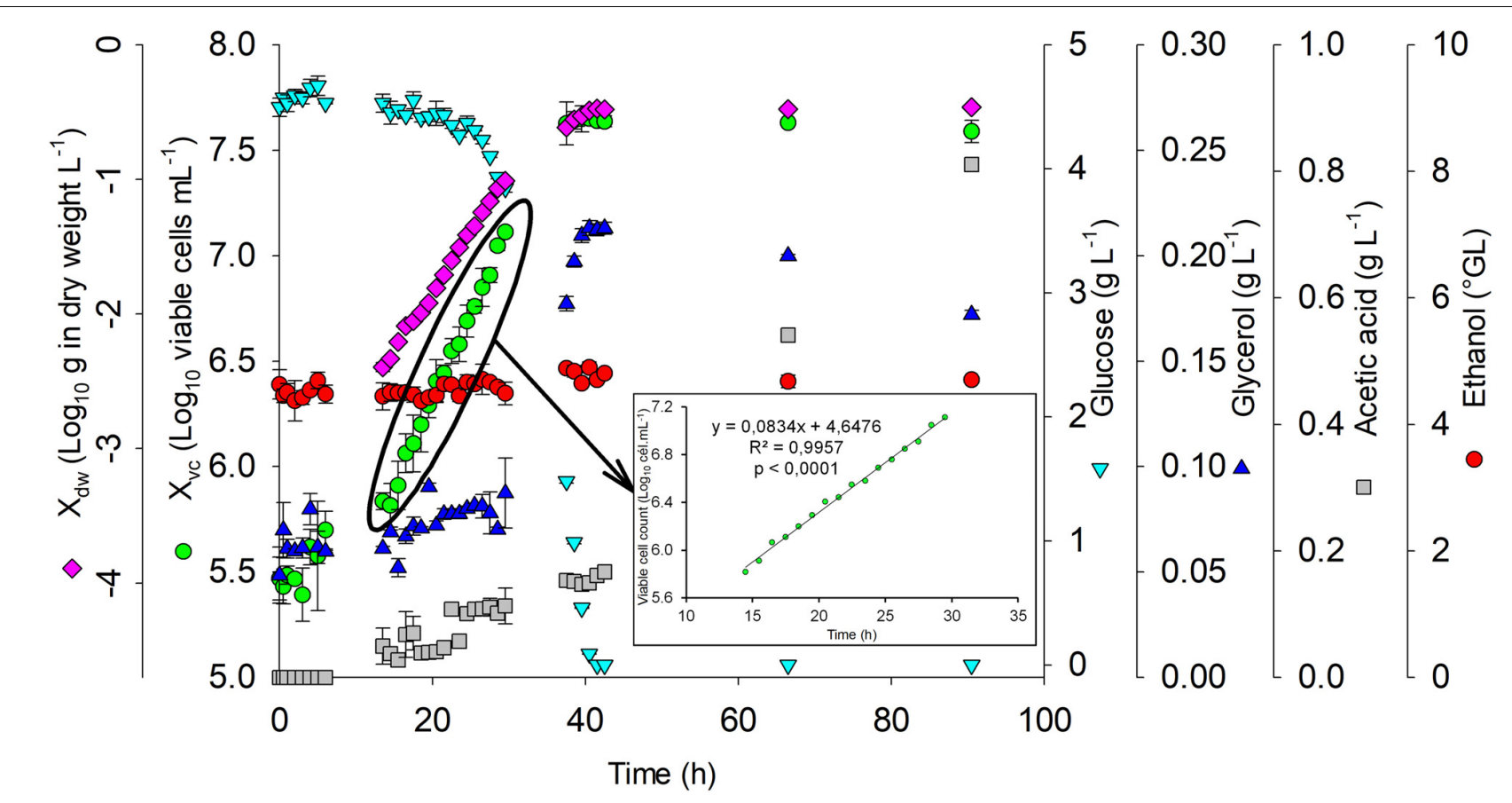

FIGURE 4 | Growth kinetics of S. boulardii. Glucose and ethanol consumption and acetic production for confirmation of the mathematical model carried out with an alcohol content $=5^{\circ} \mathrm{GL}, \mathrm{pH}=5.5$, and temperature $=24^{\circ} \mathrm{C} . \mathrm{X}_{\mathrm{dw}}, \mathrm{S}$. boulardii biomass formation (Log $\mathrm{L}_{10} \mathrm{~g}_{\text {in }} \mathrm{dry} \mathrm{weight}^{-1}$ ); $\mathrm{X}_{\mathrm{vc}}$, viable $\mathrm{S}$. boulardii concentration ( $\log _{10}$ viable cells $\left.\mathrm{mL}^{-1}\right) ; \mathrm{g} \mathrm{L}^{-1}$, glucose; $g \mathrm{~L}^{-1}$, glycerol; $g \mathrm{~L}^{-1}$, acetic acid; ${ }^{\circ} \mathrm{GL}$, ethanol.

During the exponential growth phase, acetic acid production $\left(0.15 \mathrm{~g} \mathrm{~L}^{-1}\right)$, glycerol production $\left(0.21 \mathrm{~g} \mathrm{~L}^{-1}\right)$, and an increase in S. boulardii concentration (5.47 to $7.63 \log _{10}$ cells $\mathrm{mL}^{-1}$ ) occurred, in addition to reductions in glucose (5.35 up to $4.53 \mathrm{~g}$ $\mathrm{L}^{-1}$ ), dissolved oxygen (6.63 up to $0.16 \mathrm{ppm}$ ), and $\mathrm{pH}$ (5.35 up to 4.53). At the end of the exponential growth phase, all the glucose was consumed, and the acetic acid production had increased to $0.81 \mathrm{~g} \mathrm{~L}^{-1}$.

Figure 5 shows the polynomial mathematical model with fixed $\mathrm{pH}(5.5)$ and $\mathrm{T}\left(24^{\circ} \mathrm{C}\right)$ to evaluate the growth of $S$. boulardii at several alcohol contents. After polynomial mathematical model validation with fixed $\mathrm{pH}$ and temperature, it was possible to verify that with alcohol content $11.3^{\circ} \mathrm{GL}$, the polynomial mathematical model indicates an viable cells concentration of $7.0 \log _{10}$ cells $\mathrm{mL}^{-1}$.

\section{DISCUSSION}

Saccharomyces boulardii is more tolerant of acidic $\mathrm{pH}$ and temperature variation than other S. cerevisiae strains and can survive at $\mathrm{pH}$ values as low as 2.0 (Moradi et al., 2018). Often, yeasts are less susceptible to ethanol than other microorganisms, especially bacterial genera. Otherwise, alcohol may modify the cell membrane permeability and negatively affect nutrient transport (Henderson and Block, 2014).

The variation between results from the polynomial mathematical model (10 $\mathrm{mL}$ screw-cap tubes) and the confirmation test ( $5 \mathrm{~L}$ bioreactor) can be explained by differences such as the volume $(10 \mathrm{~mL}$ against 5 Land geometric design, which is the constant relation between the corresponding linear dimensions in the two scales (diameter and height). Inconsistent environmental conditions sometimes lead to different and unsatisfactory results at the laboratory or pilot scale due to physiological changes in the microorganism activity (Pereira et al., 2008). When the experiment was carried out in a screwcap tube $(10 \mathrm{~mL})$, the biomass formation was higher than that produced in the bioreactor, but the cell number was not. Therefore, the geometric dimensions seem to have a stronger effect on the cell size than on the number of cells. According to Costa (2017), environmental stress conditions, such as alcoholic stress and oxidative stress, lead to metabolic modification aimed at cell protection. Oxidative stress is the response to damage caused by excess reactive oxygen species (superoxide anion, hydrogen peroxide, and hydroxyl radical) or by changes in the cellular redox status (Smart, 2008), and alcoholic stress is the response to the presence of ethanol in the medium, which at low concentrations acts as a growth inhibitor in yeast, inhibiting cell division and decreasing cell volume and growth rate, and at high concentrations reduces vitality and increases cell death (Birch and Walker, 2000). Oxidative stress affects proteins, lipids, and deoxyribonucleic acid (DNA) in different cell structures, and alcoholic stress mainly affects cell membranes, proteins and the endoplasmic reticulum, leading to the expression of genes for response to environmental stress, especially heat shock proteins (Costa, 2017). In the polynomial mathematical model validation experiment, the addition of ethanol and correction of the $\mathrm{pH}$ of the culture medium were performed in the bioreactor under 


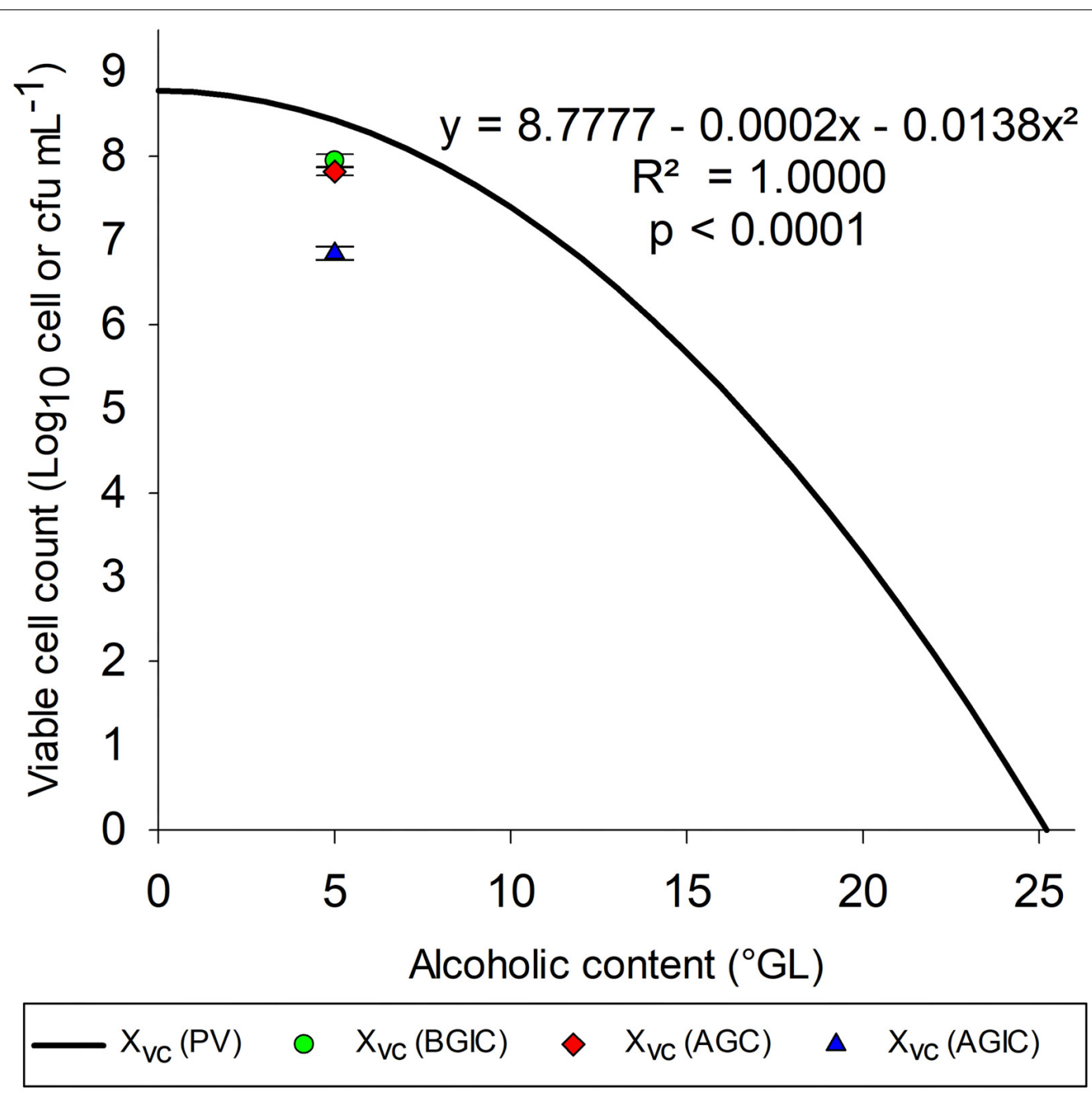

FIGURE 5 | Tolerance of S. boulardii to medium containing ethanol. $X_{v c}(P V)=$ viable cell concentration $\left(\log _{10}\right.$ viable cells $\left.\mathrm{mL}^{-1}\right)$ values predicted by the mathematical model with $\mathrm{pH}$ and temperature set to 5.5 and $24^{\circ} \mathrm{C}$, respectively; $X_{v c}(B G I C)$, viable cell concentration before gastrointestinal conditions ( $L$ og ${ }_{10}$ cfu $\left.\mathrm{mL}^{-1}\right) ; X_{\mathrm{vc}}(\mathrm{AGC})$, concentration of viable cells after gastric conditions $\left(\log _{10} \mathrm{Cfu} \mathrm{mL}^{-1}\right)$; $\mathrm{X}_{\mathrm{vc}}(\mathrm{AGIC})$, concentration of viable cells after gastrointestinal conditions $\left(\log _{10} \mathrm{cfu} \mathrm{mL} \mathrm{L}^{-1}\right)$.

constant stirring $(160 \mathrm{rpm})$, causing oxygenation in the culture medium, which together with the difference in the geometric design of the reactor and the presence of ethanol may have increased cell stress, causing the smaller size of $S$. boulardii cells in comparison to that in the screening tests.

Trigueros et al. (2016) developed assays for the modeling and optimization of culture medium using hydrolyzed cheese whey permeate as a substrate for fermentation with $S$. boulardii. The models showed that the optimal $\mathrm{pH}$ for microorganism growth was between 4.5 and 5.5 with specific growth rate $\left(\mu_{\mathrm{X}}\right)$ equal to $0.17 \mathrm{~h}^{-1}$. The experiment was carried out in medium without ethanol incubated at $30^{\circ} \mathrm{C}$. Thus, the value obtained by calculating rate of substrate utilization $\left(\mu_{S}\right)$ indicates that in the exponential phase, $3.13 \times 10^{-12} \mathrm{~g}$ glucose was consumed per cell of $S$. boulardii per hour. Similarly, the value obtained for conversion factor of substrate into biomass $\left(\mathrm{Y}_{\mathrm{X} / \mathrm{S}}\right)$ indicates that for $S$. boulardii, the growth of $1.42 \times 10^{10}$ cells occurred per $g$ of glucose consumption.

Muller et al. (2007) compared S. boulardii growth in air lift and shaker bioreactors, obtaining values of specific growth rate between 0.350 and $0.382 \mathrm{~h}^{-1}$ for with an initial $\mathrm{pH}$ of 6.0 and incubation at $30^{\circ} \mathrm{C}$ in the absence of ethanol in the culture medium. The values reported by Muller et al. (2007) demonstrate consistency with the values obtained in this work, especially in a culture medium containing ethanol.

McFarland (2017) prescribed a minimum (9.0 $\log _{10}$ cell) dose of $S$. boulardii to confer health benefits on humans. Thus, probiotic alcoholic beverage benefits may be obtained from the intake of approximately $100 \mathrm{~mL}$ of the drink, but this value depends on its alcohol content. In this work, S. boulardii survivability showed a slight reduction of $0.13 \log _{10} \mathrm{cfu} \mathrm{mL} \mathrm{L}^{-1}$ after gastric conditions and $0.97 \log _{10} \mathrm{cfu} \mathrm{mL}^{-1}$ after intestinal 
conditions (total reduction of $1.10 \log _{10} \mathrm{cfu} \mathrm{mL}^{-1}$ ), with a survivability of $6.85 \log _{10} \mathrm{cfu} \mathrm{mL}^{-1}$ after gastrointestinal conditions in culture medium with $5.0^{\circ} \mathrm{GL}$.

Enough viable probiotics are necessary to play a beneficial role on the host (Joint FAO/WHO Working Group, 2002). Gastrointestinal resistance is also an important property to probiotics when gut microbiome balance is the target; however, only alive microorganisms can confer additional benefits. Beer is so stressful matrix to the microorganisms, once alcohol and acids produced during the fermentation can damage cells over storage period. Thus, GI transit is an overlapping stress factor to the yeast after brewing. Probiotic alcoholic beverage benefits may be obtained from the intake of approximately $100 \mathrm{~mL}$ of the drink, but this value depends on its alcohol content. In this work, $S$. boulardii survivability showed a slight reduction of 0.13 and $0.97 \log _{10} \mathrm{cfu} \mathrm{mL}^{-1}$ after gastric conditions and intestinal conditions, respectively, with a survivability of 6.85 $\log _{10} \mathrm{cfu} \mathrm{mL}^{-1}$ after gastrointestinal transit in culture medium with $5.0^{\circ} \mathrm{GL}$.

According to Stackelberg et al. (2014), moderate alcohol consumption may reduce the risk of abdominal aortic aneurysm in both men and women. Therefore, moderate alcohol consumption is not harmful, and non-distilled alcoholic beverages may have protective properties against the development of abdominal aortic aneurysm. The effect of higher doses of alcohol on the risk of disease remains unknown. Moderate consumption standard: one standard dose (12 g ethanol) was calculated as $150 \mathrm{~mL}$ of wine, $80 \mathrm{~mL}$ of strong wine, $660 \mathrm{~mL}$ of Class I beer $\left(<2.25^{\circ} \mathrm{GL}\right), 500 \mathrm{~mL}$ of Class II beer $\left(2.25-3.5^{\circ} \mathrm{GL}\right), 330 \mathrm{~mL}$ of Class III beer $\left(\geq 3.5^{\circ} \mathrm{GL}\right)$, or $40 \mathrm{~mL}$ of liquor. Markus et al. (2015) found that light to moderate alcohol consumption was associated with a lower risk of developing aortic valve sclerosis both in men and women. These results are in accordance with the objective of this work, which was to optimize the growth of $S$. boulardii, allowing the development of probiotic alcoholic beverage to obtain additional benefits. According to the results obtained using the polynomial mathematical model, it is possible to produce a probiotic wine with alcohol content equal $11.9^{\circ} \mathrm{GL}$, obtaining viable cell concentration $6.82 \log _{10}$ viable cells $\mathrm{mL}^{-1}$. Following the criteria adopted by Stackelberg et al. (2014) of moderate wine consumption, $150 \mathrm{~mL}$ allows the ingestion of $9.00 \log _{10}$ viable cells, which corresponds to the minimum value indicated by McFarland (2017). Similarly, for the results obtained in the polynomial mathematical model validation test $\left(7.63 \log _{10}\right.$ viable

\section{REFERENCES}

Adinarayana, K., Ellaiah, P., Srinivasulu, B., Devi, R. B., and Adinarayana, G. (2003). Response surface methodological approach to optimize the nutritional parameters for neomycin production by Streptomyces marinensis under solidstate fermentation. Process Biochem. 38, 1565-1572. doi: 10.1016/S00329592(03)00057-8

Altmann, M. (2018). The Benefits of Saccharomyces Boulardii. London: IntechOpen.

Bagherpour, G., Ghasemi, H., Zand, B., Zarei, N., Roohvand, F., Ardakani, E. M., et al. (2018). Oral administration of recombinant Saccharomyces boulardii cell $\mathrm{mL}^{-1}$ ) with alcohol content equal $5^{\circ} \mathrm{GL}$, corresponding to a Class III beer, it would be necessary to ingest only $23.44 \mathrm{~mL}$, well below $330 \mathrm{~mL}$ (Stackelberg et al., 2014), to meet the minimum concentration indicated by McFarland (2017).

The minimum sensory limit for acetic acid perception is $0.07 \mathrm{~g}$ $\mathrm{L}^{-1}$ (Zhang et al., 2012). Therefore, stopping the fermentation before the stationary phase is extremely important to ensure that acetic acid production is lower than the perception sensory limit. Often, the acetic acid concentration in different styles of beers ranges from 0.06 to $0.15 \mathrm{~g} \mathrm{~L}^{-1}$. At the beginning of the stationary phase, the glycerol concentration was $0.18 \mathrm{~g} \mathrm{~L}^{-1}$. According to Zhao et al. (2015), glycerol is significantly related to the density and viscosity of beer, and its sensory perception level is $10 \mathrm{~g} \mathrm{~L}^{-1}$.

Saccharomyces boulardii may have good potential for probiotic alcoholic beverage development. Slight microbial susceptibility to gastrointestinal conditions was observed, and alcohol exhibited no severe stress on $S$. boulardii survivability. The results provide new insight into the management of probiotic beverages and suggest new prospects for a more integrated strategy for increasing beverage quality.

\section{DATA AVAILABILITY}

All datasets generated for this study are included in the manuscript and/or the supplementary files.

\section{AUTHOR CONTRIBUTIONS}

BP participated in the planning, conducted the experiments, and wrote and revised the manuscript. DC assisted in the statistical analysis and revised the manuscript. WL and AG assisted in the microbiological analyses and reviewed the manuscript. MCor performed the chromatographic analyses and revised the manuscript. KP and MCoe planned and coordinated the experiments, and revised the manuscript.

\section{FUNDING}

This study was financed in part by the Coordenação de Aperfeiçoamento de Pessoal de Nível Superior - Brasil (CAPES) - Finance Code 001. MCoe thanks CNPq (Brazil) for financial support.

expressing ovalbumin-CPE fusion protein induces antibody response in mice. Front. Microbiol. 9:723. doi: 10.3389/fmicb.2018.00723

Birch, R. M., and Walker, G. M. (2000). Influence of magnesium ions on heat shock and ethanol stress responses of Saccharomyces cerevisiae. Enzyme Microb. Technol. 26, 678-687. doi: 10.1016/S0141-0229(00)00159-9

Candioti, L. V., De Zan, M. M., Camara, M. S., and Goicoechea, H. C. (2014). Experimental design and multiple response optimization. Using the desirability function in analytical methods development. Talanta 124, 123-138. doi: 10. 1016/j.talanta.2014.01.034

Costa, A. C. T. (2017). Resposta a Estresses Consecutivos Em Saccharomyces Cerevisiae, Ph.D. thesis, Universidade Federal do Espirito Santo, Vitória, ES. 
Derrien, M., Badr, A., Gosselin, A., Desjardins, Y., and Angers, P. (2017). Optimization of a green process for the extraction of lutein and chlorophyll from spinach by-products using response surface methodology (RSM). LWT Food Sci. Technol. 79, 170-177. doi: 10.1016/j.lwt.2017.01.010

Fijan, S. (2014). Microorganisms with claimed probiotic properties: an overview of recent literature. Int. J. Environ. Res. Public Health. 11, 4745-4767. doi: 10.3390/ijerph110504745

Floch, M. H. (2017). The role of prebiotics and probiotics in gastrointestinal disease. Gastroenterol. Clin. North Am. 47, 179-191. doi: 10.1016/j.gtc.2017. 09.011

Guerra, A. F., Lemos Junior, W. J. F., Santos, G. O., Andrighetto, C., Gianomini, A., Corich, V., et al. (2018). Lactobacillus paracasei probiotic properties and survivability under stress-induced by processing and storage of ice cream bar or icelolly. Ciênc Rural. 48, 1-9. doi: 10.1590/0103-8478cr2017 0601

Henderson, C. M., and Block, D. E. (2014). Examining the role of membrane lipid composition in determining ethanol tolerance of Saccharomyces cerevisiae. Appl. Environ. Microbiol. 80, 2966-2972. doi: 10.1128/AEM.04151-13

Hill, C., Guarner, F., Reid, G., Gibson, G. R., Merenstein, D. J., Pot, B., et al. (2014). The international scientific association for probiotics and prebiotics consensus statement on the scope and appropriate use of the term probiotic. Nat. Rev. Gastroenterol. Hepatol. 11, 506-514. doi: 10.1038/nrgastro.2014.66

ISO 7218, (2007). Microbiology of food and Animal Feeding Stuffs - General Requirements and Guidance for Microbiological Examinations. London: British Standards Institution.

Joint FAO/WHO Working Group (2002). Guidelines for the Evaluation of Probiotics in Food. Available at: http://www.who.int/foodsafety/fs_management/en/ probiotic_guidelines.pdf (accessed May 24, 2019).

Kristo, E., Biliaderis, C. G., and Tzanetakis, N. (2003). Modelling of the acidification process and rheological properties of milk fermented with a yogurt starter culture using response surface methodology. Food Chem. 83, 437-446. doi: 10.1016/S0308-8146(03)00126-2

Lee, K. M., and Gilmore, D. F. (2005). Formulation and process modeling of biopolymer (polyhydroxyalkanoates: PHAs) production from industrial wastes by novel crossed experimental design. Process Biochem. 40, 229-246. doi: 10. 1016/j.procbio.2003.12.007

Lemos Junior, W. J. F., Guerra, A. F., Tarrah, A., da Silva Duarte, V., Giacomini, A., Luchese, R. H., et al. (2019). Safety and stability of two potentially probiotic lactobacillus strains after in vitro gastrointestinal transit. Probiotics Antimicrob. Proteins doi: 10.1007/s12602-019-09565-2 [Epub ahead of print].

Lemos Junior, W. J. F., Viel, A., Bovo, B., Carlot, M., Giacomini, A., and Corich, V. (2017). Saccharomyces cerevisiae vineyard strains have different nitrogen requirements that affect their fermentation performances. Lett. Appl. Microbiol. 65, 381-387. doi: 10.1111/lam.12798

Markus, M. R. P., Lieb, W., Stritzke, J., Siewert, U., Troitzsch, P., Koch, M., et al. (2015). Light to moderate alcohol consumption is associated with lower risk of aortic valve sclerosis: the study of health in pomerania (SHIP). Arterioscler. Thromb. Vasc. Biol. 35, 1265-1270. doi: 10.1161/ATVBAHA.114.304831

McFarland, L. V. (2017). Chapter 18 - Common Organism and Probiotics: Saccharomyces boulardii. In The Microbiota in Gastrointestinal Pathophysiology. Cambridge, MA: Academic Press, 145-164.

Moradi, R., Nosrati, R., Zare, H., Tahmasebi, T., Saredi, H., and Owlia, P. (2018). Screening and characterization of in-vitro probiotic criteria of Saccharomyces and Kluyveromyces strains. Iran. J. Microbiol. 10, 123-131.

Muller, J. L., Protti, K. L., Machado, M. S., Lacerda, L. L. V., Bresolin, T. M. B., and Podlech, P. S. (2007). Comparação do crescimento de Saccharomyces boulardii em fermentador por batelada tipo air lift e shaker. Ciênc. Tecnol. Aliment. 27, 688-693. doi: 10.1590/S0101-20612007000400003
Myers, R. H., Montgomery, D. C., and Anderson-Cook, C. M. (2016). Response Surface Methodology: Process and Product Optimization using Designed Experiments. Hoboken, NJ: John Wiley \& Sons.

Pereira, N. J., Bom, E. P. S., and Ferrara, M. A. (2008). Séries Em Biotecnologia: Tecnologia De Bioprocessos. Rio de Janeiro: Copiadora Amiga dos Estudantes Ltd.

Plackett, R. L., and Burman, J. P. (1946). The design of optimum multifactorial experiments. Biometrika 33, 305-325. doi: 10.1093/biomet/33.4.305

Silva, A. P., Jager, G., van Bommel, R., van Zyl, H., Voss, H. P., Hogg, T., et al. (2016). Functional or emotional? How dutch and portuguese conceptualise beer, wine and non-alcoholic beer consumption. Food Q. Prefer. 49, 54-65. doi: 10.1016/j.foodqual.2015.11.007

Smart, K. (2008). Brewing Yeast Oxidative Stress Responses: Impact of Brewery Handling. In: Brewing Yeast Fermentation Performance, 2nd Edn. Hoboken, NJ: Blackwell Scienve Ltd.

Spigno, G., Garrido, G. D., Guidesi, E., and Elli, M. (2015). Spray-drying encapsulation of probiotics for ice-cream application. Chem. Eng. Trans. 43, 49-54. doi: 10.3303/CET1543009

Stackelberg, O., Björck, M., Larsson, S. C., Orsini, N., and Wolk, A. (2014). Alcohol consumption, specific alcoholic beverages, and abdominal aortic aneurysm. J. Vasc. Surg. 61, 646-652. doi: 10.1161/CIRCULATIONAHA.113.008279

Szajewska, H., and Kołodziej, M. (2015). Systematic review with meta-analysis: Saccharomyces boulardii in the prevention of antibiotic-associated diarrhoea. Aliment. Pharmacol. Ther. 42, 793-801. doi: 10.1111/apt.13344

Terciolo, C., Dapoigny, M., and Andre, F. (2019). Beneficial effects of Saccharomyces boulardii CNCM I-745 on clinical disorders associated with intestinal barrier disruption. Clin. Exp. Gastroenterol. 12, 67-82. doi: 10.2147/ CEG.S181590

Tomičić, Z., Colovic, R., Cabarkapa, I., Vukmirovic, D., Djuragic, O., and Tomicic, R. (2016). Beneficial properties of probiotic yeast Saccharomyces boulardii. Food Feed Res. 43, 103-110. doi: 10.5937/FFR1602103T

Trigueros, D. E. G., Fiorese, M. L., Kroumov, A. D., Hinterholz, C. L., Nadai, B. L., and Assunção, G. M. (2016). Medium optimization and kinetics modeling for the fermentation of hydrolyzed cheese whey permeate as a substrate for Saccharomyces cerevisiae var. boulardii. Biochem. Eng. J. 110, 71-83. doi: 10. 1016/j.bej.2016.02.014

Zhang, Y., Jia, S., and Zhang, W. (2012). Predicting acetic acid content in the final beer using neural networks and support vector machine. J. Inst. Brew. 118, 361-367. doi: 10.1002/jib.50

Zhao, X., Procopio, S., and Becker, T. (2015). Flavor impacts of glycerol in the processing of yeast fermented beverages: a review. J. Food Sci. Technol. 52, 7588-7598. doi: 10.1007/s13197-015-1977-y

Zhi, W., Song, J., Ouyang, F., and Bi, J. (2005). Aplicação da metodologia de superfície de resposta na modelagem da purificação de $\alpha$-amilase por sistemas aquosos bifásicos. J. Biotechnol. 118, 157-165. doi: 10.1016/j.jbiotec.2005. 03.017

Conflict of Interest Statement: The authors declare that the research was conducted in the absence of any commercial or financial relationships that could be construed as a potential conflict of interest.

Copyright (c) 2019 Paula, Chávez, Lemos Junior, Guerra, Corrêa, Pereira and Coelho. This is an open-access article distributed under the terms of the Creative Commons Attribution License (CC BY). The use, distribution or reproduction in other forums is permitted, provided the original author(s) and the copyright owner(s) are credited and that the original publication in this journal is cited, in accordance with accepted academic practice. No use, distribution or reproduction is permitted which does not comply with these terms. 